\title{
Empirical Study to Evaluate the Economic Resilience of Agricultural Household with Adjusted Living Standard Index (ALSI) Approached (Case Study for Victims of Merapi's Eruption 2012)
}

\author{
Muhamad Fathul Muin ${ }^{1}$ \\ ${ }^{1}$ Badan Pusat Statistik Provinsi Papua, Jayapura 99112, Indonesia \\ Email :*muhamad.fathul.muin@gmail.com
}

Dikirim : 5 April 2019

Diterima: 19 Mei 2019

\begin{abstract}
Abstrak: Bencana dapat menyebabkan perekonomian hancur, terutama sektor pertanian di empat kabupaten: Magelang, Sleman, Klaten, dan Boyolali. Untuk mengevaluasi kondisi ekonomi korban bukanlah sesuatu hal yang mudah, sehingga memerlukan pendekatan alternatif. Oleh karena itu, tujuan dari makalah ini adalah mengevaluasi ketahanan ekonomi korban menggunakan indeks komposit, uji-t, uji berpasangan, dan ANOVA unbalanced. Penelitian ini berhasil membangun indikator yang disebut The Adjusted Living Standard Index (ALSI) untuk pendekatan standar hidup. Dimensi yang digunakan terdiri atas pendapatan, transfer sosial, aset non produktif, dan aset produktif. Studi ini juga menemukan bahwa standar hidup para korban sebelum erupsi di seluruh daerah tergolong rendah. Namun pasca bencana menyebabkan dimensi standar kehidupan mengalami penurunan secara signifikan, kecuali transfer sosial. Disisi lain, setelah dua puluh dua bulan masyarakat mengalami pemulihan. Hanya saja uji statistik menunjukkan bahwa banyak perbedaan dalam ketahanan ekonomi yang disebabkan oleh komponen transfer sosial. Sehingga untuk membuat masyarakat lebih resilience, diperlukan kebijakan yang mendukung serta penyediaan asuransi.
\end{abstract}

Kata kunci: pendekatan alternatif, indeks komposit, ekonomi rumah tangga, bencana alam, bencana gunung api.

\begin{abstract}
Disaster made the economic gotten destroyed, especially for the agricultural sector in four regencies: Magelang, Sleman, Klaten, and Boyolali. To evaluate the economics of victim's society isn't easy and need the alternative approached. So the aim of this paper to evaluate them use the composite index, t-test, t paired test, and unbalanced ANOVA. This research success to construct a new tool named The Adjusted Living Standard Index (ALSI) to approach the living standard. The dimension used consisted of income, social transfer, nonproductive assets, and productive assets. This study also founded that living standard of victims pra eruption all of the regions is low. The disaster tragedy made the dimensions of living standard fall down significantly, except for social transfer. However, after twenty-two months they have the recovery as well. But, the statistical tests showed that most of them have the difference in economic resilience caused by social transfer component. To make them more resilience, they need to strengthen supporting policy and insurance.
\end{abstract}

Keywords: alternative approached, composite index, household economic, natural hazard, volcanic disaster.

\section{Introduction}

Disaster is a natural hazard which a negative effect for economic (Hallegatte, 2014). It made decrease for production, investment, consumption, income and job opportunity (Hallegatte, 2014). Generally, the impact is greater than the society-environment ability and it makes the economic system can't solve it. In this situation, the economic system suffered the cost (Silbert, 2011) and the society loss the welfare (Hallegatte, 2015). In the case of 2010 Merapi's eruption, this calamity gives the impact to economic performance, especially who lives in four Regency: 
Magelang, Sleman, Klaten, and Boyolali. Based on BNPB - UNDP's report (2013), most of the sectors get the negative impact caused by Merapi eruption, especially the agricultural sector. One famous concept studying about the recovery from disaster is resilience, which defined as ability/capability from the household to prevent the potential loss (Rose, 2009), managed the change and maintain the ability to keep the living standard (Dinh \& Pearson, 2015). Normally, to evaluate a region for recovery, most of the researcher use GDP as the indicator. But the resilience actually is a complicated concept (Lisnyak, 2015), so the GDP can't use to describe it clearly (Stiglitz, Sen, \& Fitoussi, 2009). The alternative indicator offered in this paper is using adjusted living standard. More than it, there is no research yet specialized for the agricultural household. Even though, the agricultural household is very important to be researched, because most of the populations stayed around Merapi have a job in the agricultural sector and mostly more vulnerable to face every shock (Harvey, et al., 2014).

\section{Materials and Methods}

The scope in this research is agricultural household which the victims of 2010 Merapi's eruption, include four regencies. They have stayed at Magelang, Boyolali, Klaten, and Sleman. The population analyzed is agriculture household which all of the household members worked in the agricultural sector. This treatment based on arguments that they would more vulnerable than the partial member worked in the agricultural sector (Kahan, 2008). The data used sourced from the Survey Meter, corporate with UNDP and BNPB which done from September to October 2012.

Infer to Kendal's, et. al (2009), the household economic resilience can be approached by the ability to keep the living standard. So in this study, there are four indicators to approximate economic resilience. They are:

a. Income, as a general indicator to evaluate the welfare (Hallegatte, 2014).

b. Social transfer, the important instrument to increase the household ability and keep the livelihood when a disaster occurs (Kilburn \& Handa, 2015). Moreover, the social transfer can improve the welfare by stimulating the production and anticipate the inequality (Künnemann \& Leonhard, 2008).

c. Nonproductive assets, as a saving instrument used to accelerate the consumption when needed (Morrone, Scrivens, Smith, \& Balestra, 2011).

d. Productive assets, as a net present value to protect from the risk, which it gives the contribution to keep the income and guarantee the economic in future (Morrone, Scrivens, Smith, \& Balestra, 2011).

All of the indicators used to construct the composite index which called Adjusted Living Standard Index (ALSI). Based on OECD (2008), Mazziato \& Pareto (2013) dan USAID (2014), there are six steps to construct the composite index, include:
a. build the theoretical framework
b. choice the indicators
c. data quality
d. statistical analysis
e. normalize data
f. weighting and aggregation

So, the formula used is $A L S I=\frac{\sum_{i=1}^{4} I_{i}}{4}$

I : indicator i-th (income, social transfer, nonproductive assets, productive assets).

After that, the ALSI is classified to:

a.

$<0.550$ : living standard is low 

b. $\quad 0.550-0.699$ : living standard is medium
c. $0.700-0.799$ : living standard is high
d. $\quad>0.800$ : living standard is very high

Furthermore, the statistical method used are t-test, $\mathrm{t}$ paired test, and unbalanced ANOVA. The t-test used to test the hypothesis that the ALSI is lower than 55. Then, the paired t-test useful to find there is no difference of ALSI between pre-eruption and after recovery. The last is unbalanced ANOVA used to statistical testing that no differences between the regency for ALSI and the dimension constructed it.

\section{Result}

\section{Construct the Adjusted Living Standard Index (ALSI)}

Each indicator constructed from a number of variable which normalized by min-max method. To create the indicator from the variable we use the equal weighting approximation, except for income used the proportional median. This treatment also implemented to construct the ALSI from the indicator because we assumed that each indicator are equally important.

Table 1: ALSI indicator constructed

\begin{tabular}{|l|l|l|}
\hline Indicator & Variable & Weight \\
\hline Income & The average household member main income & 0,2320 \\
\cline { 2 - 3 } & The average household member another income & 0,0180 \\
\hline Social transfer & $\begin{array}{l}\text { The sum of social transfer include the money and food from } \\
\text { government }\end{array}$ & 0,0625 \\
\cline { 2 - 3 } & $\begin{array}{l}\text { The sum of social transfer include the money and food from } \\
\text { NGO }\end{array}$ & 0,0625 \\
\cline { 2 - 3 } & $\begin{array}{l}\text { The sum of social transfer include the money and food from } \\
\text { blood family }\end{array}$ & 0,0625 \\
\cline { 2 - 3 } & $\begin{array}{l}\text { The sum of social transfer include the money and food from } \\
\text { neighbor }\end{array}$ & 0,0625 \\
\hline \multirow{5}{*}{$\begin{array}{l}\text { Nonproductive } \\
\text { assets }\end{array}$} & The sum of jewelries & 0,0625 \\
\cline { 2 - 3 } & The sum bicycle have & 0,0625 \\
\cline { 2 - 3 } & The sum motorcycle have & 0,0625 \\
\cline { 2 - 3 } & The sum of fowl have (nonbusiness purpose) & 0,0625 \\
\hline Productive assets & The sum of land area & 0,0625 \\
\cline { 2 - 3 } & The sum of cattle & 0,0625 \\
\cline { 2 - 3 } & The sum of poultry & 0,0625 \\
\cline { 2 - 3 } & The total of nonagricultural business assets & 0,0625 \\
\hline
\end{tabular}

\section{Living Standard Pre Eruption}

The farm household show that income and social transfer in each district were low, which the pattern similar to the both of assets. Generally, based on figure 1. we can see that society depend highly with the social transfer (Koutsampelas, 2011) and confirmed that household economics in the farm sector are less prosperous. 


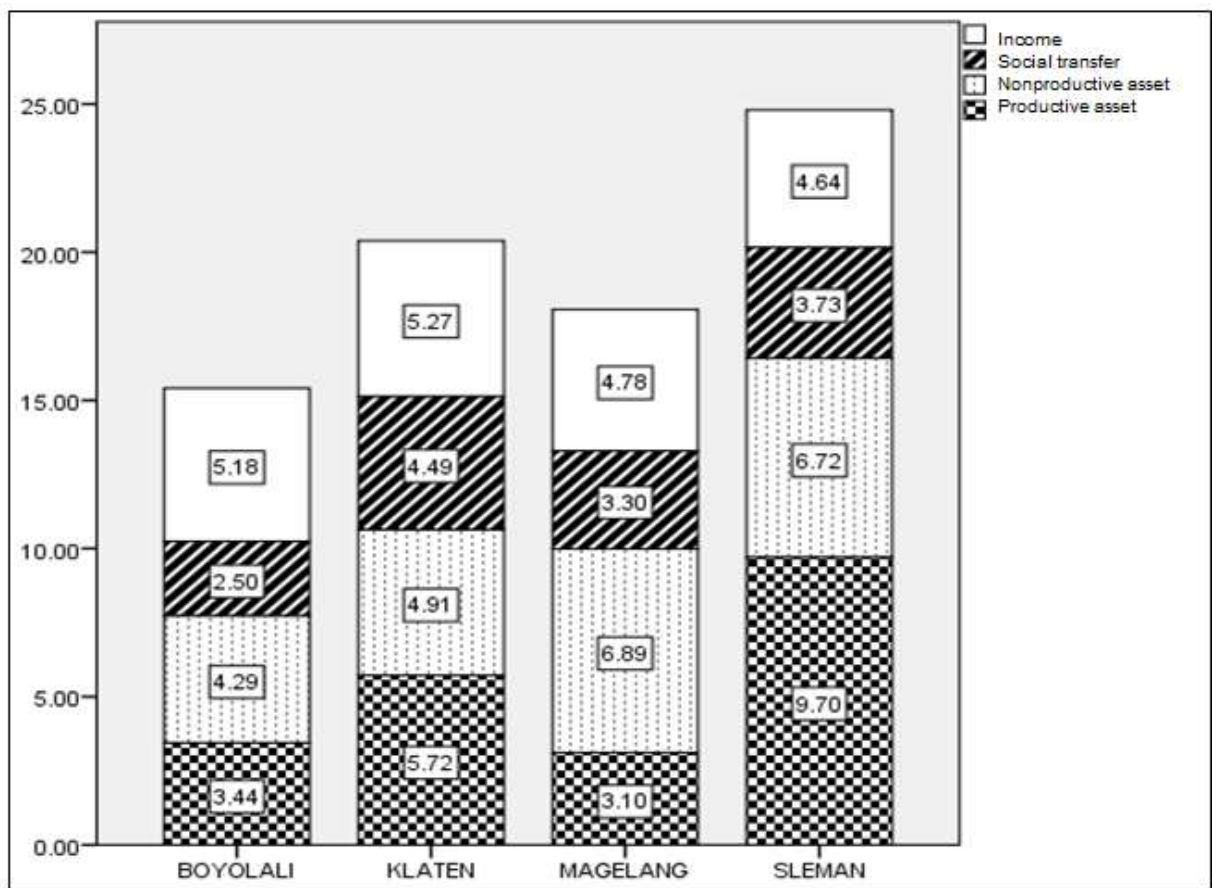

Figure 1: ALSI per dimension

\section{The Household Economic Resilience}

After the volcanic explosion occurs at 2010 render every ALSI dimension decrease, except in the social transfer. The income decreased explain that the livelihood fell down and the farm household endures the loss. After twenty-two months, the three dimensions have recovered. For the income dimension case, it supported by the high power struggle in the farm household itself (Zedlewski, et al., 2003), appearing the new opportunity job like the volcano tour (Wijayanti), sand quarry (Habibullah, 2015), and the recovery of agricultural land. The dimension of assets be through the same thing, it explained that income and social transfers have a positive impact to boost the household repurchase the lost assets (Umeh \& Asogwa, 2012). 


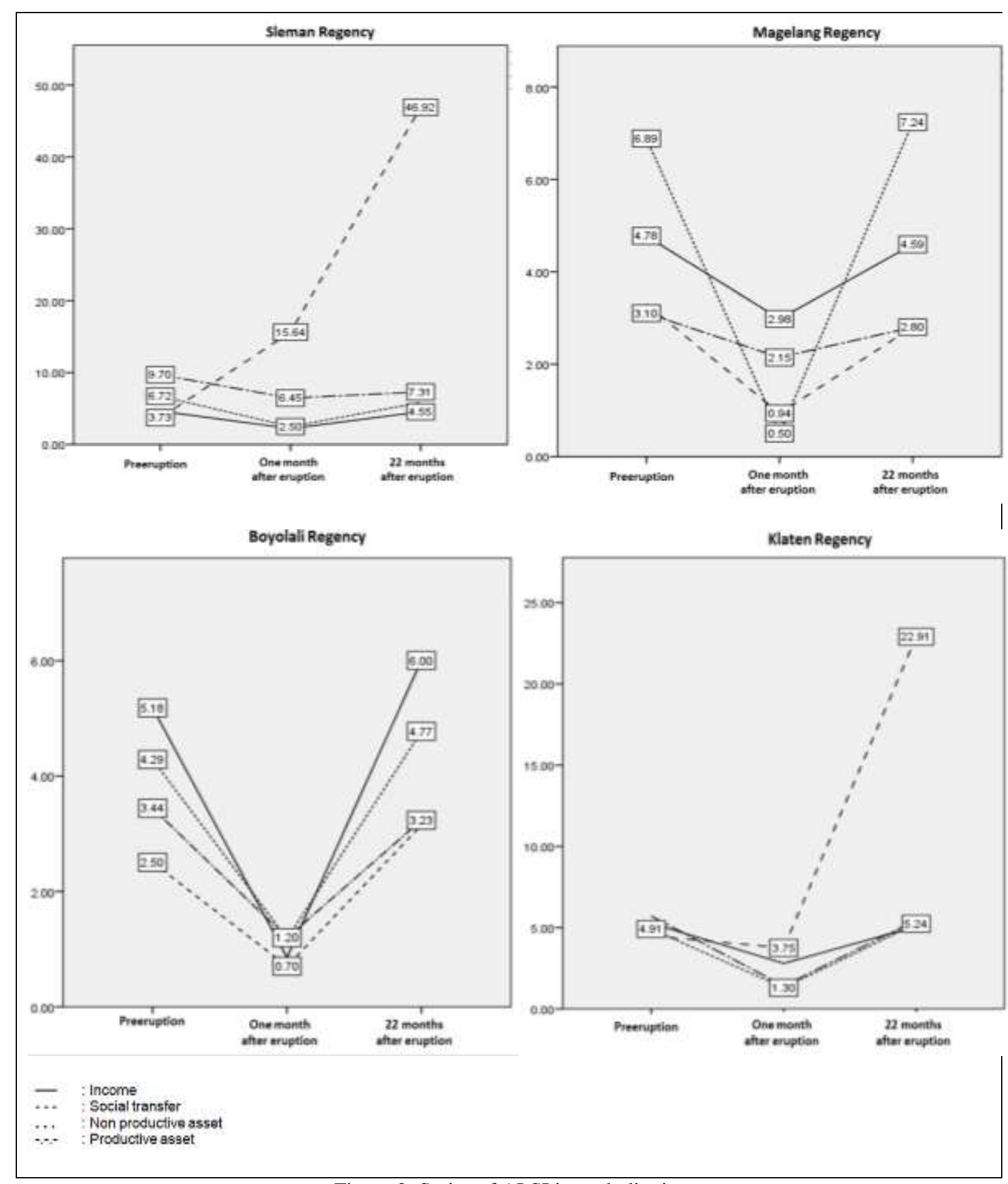

Figure 2: Series of ALSI in each district

Based on the explained before, we tested the hypothesis of economic resilience by ALSI differenced in two period time. Showed at table 2, $t$ observation resulted greater than $t$ table as generally. It concluded that statistically, the agricultural household in each regency have the resilience in economic. The interesting fact that household which low living standard doesn't implicate for slowing recovery/low resilience (Austin, et al., 2004). It possible happen reasoned by social transfer received which substituted the loss of income and assets (Holmes \& Bhuvanendra). 
Table 2: The ALSI recovery / economic resilience

\begin{tabular}{l|l|l|l|l|}
\cline { 2 - 5 } \multicolumn{1}{c|}{} & \multicolumn{1}{c}{ Boyolali } & Klaten & \multicolumn{1}{l|}{ Magelang } & Sleman \\
\hline Difference ALSI & 1,75 & 18,29 & $-0,62$ & 39,83 \\
\hline$t$ observation & 1,693 & 2,796 & $-0,760$ & 4,684 \\
\hline$t$ table & 1,6683 & 1,7011 & 1,6570 & 1,6698 \\
\hline
\end{tabular}

\section{Comparison The Economic Resilience Between The Regency}

Even though the households have recovered, the achievement in each region was different. Presented at table 3, it signifies that resilience is contrast for each regency, except between Magelang and Boyolali. Overall, the sequence of the greatest resilience is Sleman, Klaten, Magelang, and Boyolali.

Table 3: Economic resilience difference testing

\begin{tabular}{|l|c|c|l|}
\hline \multirow{2}{*}{ Kabupaten } & \multicolumn{2}{|c|}{ Sig. } & \multirow{2}{*}{ Conclusion } \\
\cline { 2 - 3 } & $\begin{array}{c}\text { ANOVA } \\
\text { Unbalanced }\end{array}$ & t test $^{* *}$ & \\
\hline Magelang - Boyolali & 0,279 & 0,074 & Not different \\
\hline Magelang - Klaten & 0,037 & 0,008 & Different \\
\hline Magelang - Sleman & 0,000 & 0,000 & Different \\
\hline Boyolali - Klaten & 0,082 & 0,019 & Different \\
\hline Boyolali - Sleman & 0,000 & 0,000 & Different \\
\hline Sleman - Klaten & 0,193 & 0,048 & Different \\
$* \quad:$ significance on post hoc tests Gamess-Howell & \\
$* * \quad:$ significance on $t$ test with equal variances not assumed & \\
\hline
\end{tabular}

Table 4: ALSI's constructed Indicator testing

\begin{tabular}{|l|c|l|}
\hline Dimension & Sig. & \multicolumn{1}{c|}{ Conclusion } \\
\hline Income & 0,535 & Not different \\
\hline Social transfer & 0,000 & Different \\
\hline Nonproductive assets & 0.091 & Not different \\
\hline Productive assets & 0,077 & Not different \\
\hline
\end{tabular}

The disparity of resilience occur by the inequality on social transfer, but not for other dimensions. It terminated the pattern of economic resilience in each district are equal basically which induced by the similarity of the land resource utilized as an agricultural field.

\section{Conclusions}

This research found the farm household has a living standard lowly. But they have a great resilience economic to confront the shock of volcanic disaster. Nonetheless, the shape of ability between the regency is diverse just caused by social transfer. The further, we suggest to strengthening the policy to build them more adaptable with disaster and provide the supporting insurance to minimalize the economic cost borne.

\section{Acknowledgments}

This paper has been extracted from author's research report approved by Mrs. Retnaningsih and Mr. I Made Arcana from Institute of Statistics, Indonesia. 


\section{References}

Austin, M. J., Chow, J., Hastings, J., Taylor, S., Johnson, M., Lemon, K., \& Leer, E. (2004). Serving Low-income Families in Poverty Neighborhoods Using Promising Programs and Practices: Building a Foundation for Redesigning Public and Nonprofit Social Services. Zellerbach Family Foundation and VanLobenSels/RembeRock Foundation.

BNPB, \& UNDP. (2013). Merapi: Pemulihan Penghidupan Warga Pasca Letusan Merapi 2010, Laporan Studi Longitudinal.

Dinh, H., \& Pearson, L. (2015). Specifying Community Economic Resilience - A Framework for Measurement. Tthe 59th AARES Annual Conference (pp. 1-19). Rotorua: Australian Agricultural \& Resource Economics Society.

Habibullah, H. (2015). Dampak Erupsi Merapi terhadap Peningkatan Perekonomian Masyarakat: Studi Penambang Pasir dan Batu di Dusun Gunung Lemah Kelurahan Gondowangi Kecamatan Sawangan Kabupaten Magelang. Yogyakarta: Universitas Islam Negeri Sunan Kalijaga.

Hallegatte, S. (2014). Natural Disasters and Climate Change. London: Springer.

Hallegatte, S. (2015). The Indirect Cost of Natural Disasters and an Economic Definition of Macroeconomic Resilience. Public Finance and Macroeconomics, Paper 3, 1-35.

Harvey, C. A., Rakotobe, Z. L., Rao, N. S., Dave, R., Razafimahatratra, H., Rabarijohn, R. H., . . MacKinnon, J. L. (2014). Extreme vulnerability of smallholder farmers to agricultural risks and climate change in Madagascar. The Royal Society Publishing, 112.

Holmes, R., \& Bhuvanendra, D. (n.d.). Social Protection and Resilient Food Systems, Summary 1: The Role of Cash Transfers.

Kahan, D. (2008). Farm Management Extension Guide: Managing Risk in Farming. Roma: FAO.

Kilburn, K., \& Handa, S. (2015). Malawi Social Cash Transfer Programme Impact Evaluation: Household Economics and Resilience at Baseline. UNC Carolina Population Center.

Koutsampelas, C. (2011). Social Transfers and Income Distribution in Cyprus. Cyprus Economic Policy Review, 5(2), 35-55.

Künnemann, R., \& Leonhard, R. (2008). A Human Rights View of Social Cash Transfers for Achieving the Millennium Development Goals. Brot für die Welt dan Evangelischer Entwicklungsdienst.

Lisnyak, S. (2015). Literature Review Regarding the Concept of Resilience and Its Assessment in the Context of the Economic Dimension. Centre for European Studies Working Paper, 7(2A), 511-518.

Mazziato, M., \& Pareto, A. (2013). Methods for Constructing Composite Indices: One for All or All for One. Rivista Italian di Economia Demografia e Statisticia, LXVII(2), 67.

Morrone, A., Scrivens, K., Smith, C., \& Balestra, C. (2011). Measuring Vulnerability and Resilience in OECD Countries. 7-8. 
OECD. (2008). Handbook on Constructing Composite Indicators: Methodology and User Guide.

Pendall, R., Foster, K. A., \& Cowell, M. (2009, Maret). Resilience and Regions: Building Understanding of the Metaphor. Cambridge Journal of Regions Economy and Society, $3(1), 71-84$.

Rose, A. Z. (2009). Defining and Measuring Economic Resilience to Earthquake. Earthquake Engineering Research Caners Program.

Silbert, M. E. (2011). Small Island Economic Vulnerability to Natural Disasters (Disertasi ed.). Gainesville: University of Florida.

Stiglitz, J. E., Sen, A., \& Fitoussi, J.-P. (2009). The Measurement of Economic Performance and Social Progress Revisited: Reflections and Overview. Paris: Centre de recherche en économie de Sciences Po.

Umeh, J. C., \& Asogwa, B. C. (2012). Determinants of Farm Household Food Expenditure: Implications for Food Security in Rural Nigeria. International Conference on Ecology, Agriculture and Chemical Engineering (pp. 212-217). Phuket: Planetary Scientific Research Center.

USAID. (2014). Design and Use of Composite Indices in Assessments of Climate Change Vulnerability and Resilience.

Wijayanti, A. R. (n.d.). Dampak Bencana Gunung Api terhadap Perubahan Mata Pencaharian: Studi Kasus: Kawasan Wisata Volcano Tour Gunung Merapi, Desa Umbulharjo, Kecamatan Cangkringan, Kabupaten Sleman. Jurnal Perencanaan Wilayah dan Kota, 89-96.

Zedlewski, S. R., Nelson, S., Edin, K., Koball, H., Pomper, K., \& Roberts, T. (2003). Families Coping without Earnings or Government Cash Assistance. Assessing the New Federalism, 1-45. 